\title{
製品紹介
}

\author{
ホットガスを利用した真空焼入れ及び浸炭マルクエンチ処理について \\ 株式会社谷口金属熱処理工業所*1

\section{Using Preheated Inactive Gas for Vacuum Hardening and Isothermal Heat Treatment after Carburizing}

Taniguchi Heat Treatment Co., Ltd.

853 Kitagawa, Saijoshi, Ehime 793-0042, Japan

(Received May 30, 2009, Accepted July 4, 2009)

\section{1.はじめに}

地球温暖化に伴い世界で頻発する異常気象により，その主 因とされている大気中二酸化炭素 $\mathrm{CO}_{2}$ 濃度の増加を食い止 めるため二酸化炭素 $\mathrm{CO}_{2}$ 排出量削減に向けて全産業および一 般市民を巻き込んで様々な活動が実施され，エコ社会化への 大きな転換期にある.

エコすなわち環境がキーワードとなっている産業にあって 熱処理業は熱を扱うためもともと二酸化炭素 $\mathrm{CO}_{2}$ 排出量の 多い環境への負荷の大きな業界である. ホットガスは, 精密 部品等の鋼材の熱処理に用いられ環境への負荷の大きいソル 卜（溶融塩）を代替する環境に優しいクリーンな熱処理媒体 として考案されたものである.

熱処理の熱媒体としてソルト（溶融塩）は劣化塩自体の廃 棄物問題に加え処理品の洗浄水の排水処理（中和，化学的酸 素要求量 $(\mathrm{COD})$, 全窒素量, 六価クロム等の対策), 塩自 体の蒸気や塩と空気中の酸素との反応生成物による作業環境 の悪化, ソルト (溶融塩) 表面からの放熱や休止時の温度保 持等で著しく低い熱効率等の問題を抱えている.

ホットガスとは予熱した不活性ガスの総称で, ソルト（溶 融塩）を使わずエコな熱処理プロセスを意図したもので，従 来は専らソルト（溶融塩）で行われていた等温熱処理への代 替適応を当初試みた第一世代の真空炉と組み合わせたタイプ のホットガス炉，現在実証試験を行っている第二世代に当た る浸炭プロセスと組み合わせた浸炭マルクエンチ炉の各々の 炉を実証のため製作 ·据付しているので，製品の紹介に併せ これまでに得られた実証試験結果について紹介する.

\section{2. ホットガス炉の基本概念}

不活性ガスとしては，最も冷却性能に優れる水素ガスさら にヘリウムガスやアルゴンガス等が有るものの経済性や安全 性等の取り扱いの観点から実用的には窒素ガス（厳密な意味 での不活性ガスではないが）が第一候補となる場合が多い。 ソルトからの代替でホットガスを使うことで廃棄物の発生, 付随する追加処理コストの発生も皆無に近く, 作業環境の悪 化をきたすこともほとんどなくクリーンファクトリー化が可 能である.

*1 =793-0042 愛媛県西条市喜多川853

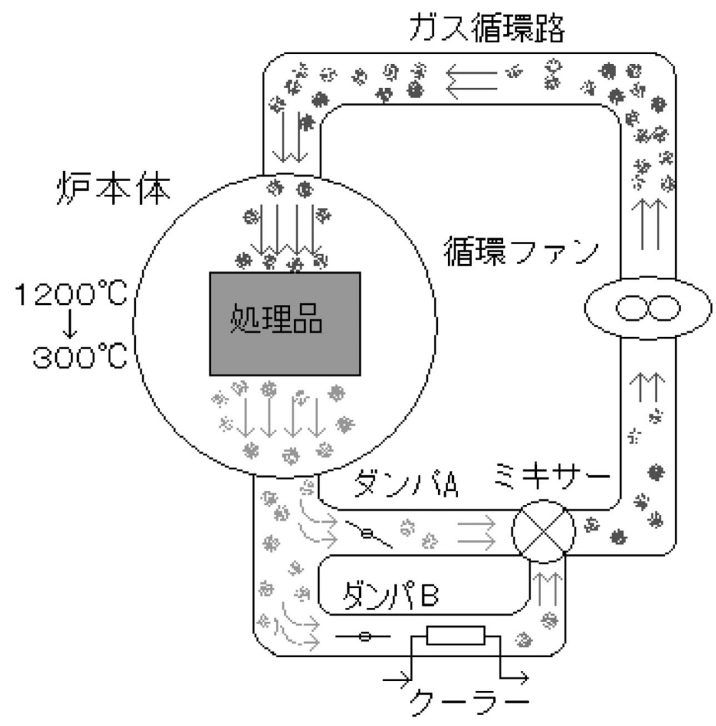

図 1 ホットガス炉の基本構造の模式図 Schematic view of the hot gas furnace

ホットガス炉の基本的な構造と機能を示したものが図 1 で ある. 熱処理炉本体の周りにホットガス用の循環路を備えフ アンにてホットガスを循環させる，循環路に分岐路を設けそ の分岐路中にクーラ（必要であればヒータ）を取付け，この 分岐路入口のダンパーの開閉によりガス流量を調整すること で簡単にかつ精度の高いホットガス温度制御が可能である. ホットガス単独では熱容量が小さく, 精度の高い安定した温 度制御を可能とするため熱容量の大きい蓄熱材を循環流路に 設置することが望ましい.さらこの蓄熱材を他の熱処理炉等 の工場排熱を利用することで $300^{\circ} \mathrm{C} レ$ ベルに予熱（加熱）し ておくことは熱を扱う工場ではそんなに困難なことではない 場合が多い.ホットガス炉を連続する熱処理の一つのモジ ュールとしてとらえた場合, 当初の狙いであった等温熱処理 プロセス（マルクエンチ，マルテンパー）のみならず焼戻プ ロセスでの適用も十分可能である。

\section{3. 真空灲タイプのホットガス炉}

ここでは，世界で初めてガスによる本格的な等温熱処理用 の実証炬を製作・据付し基礎実験を実施したのでこの実証炉 を中心に説明を行うものとする. 真空炉タイプとして炉構成 で分類すると (1)一炉完結タイプ, (2)処理品が内部の室を移動 


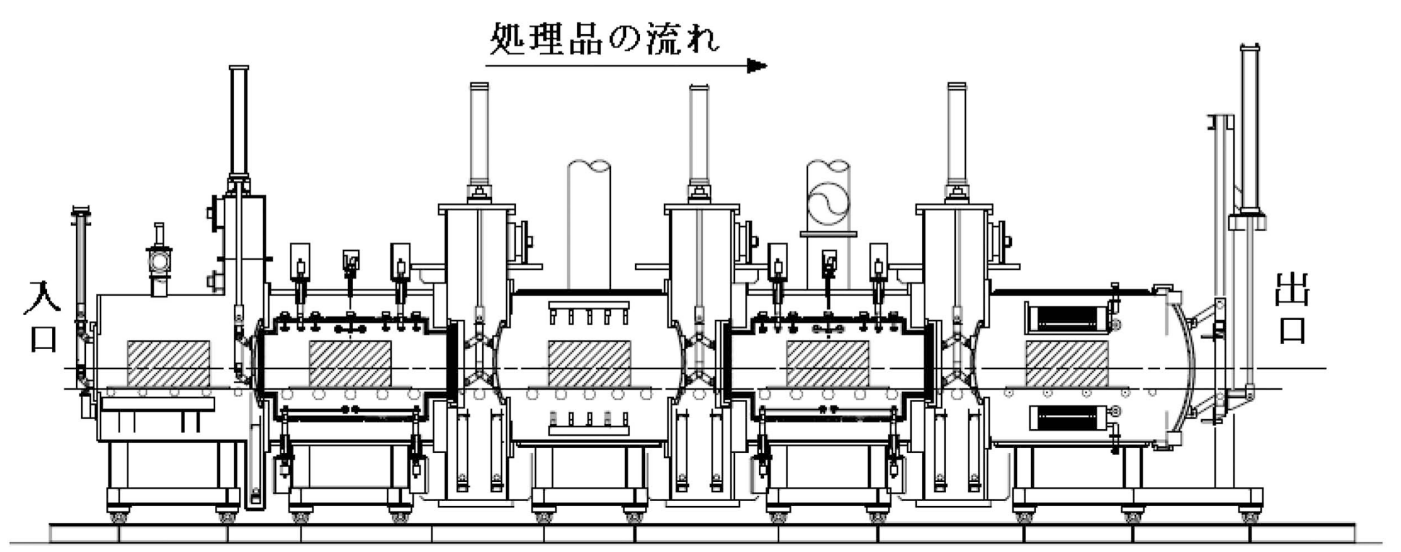

前室 加熱室 第 1 冷却室 等温冷却室 第 2 冷却室

図 2 ホットガス方式の真空炉の連続炉タイプ

Continuous type of vacuum furnace by the use of hot gas

する多室タイプ, (3)連続炉タイプ の 3 種類となる. (1)の 一怩完結タイプは最も汎用性があるタイプで通常の真空焼入 炬ではガス冷却用の熱交換器だけであるのに対してホットガ ス予熱用の熱交換器をも併せ持つものである. (2)の多室タイ プのものは熱処理サイクルのサブプロセスを別々の室に独立 対応させる形式の炉である. (3)の連続炉タイプの 5 室連続 炉を実証炉として製作し弊社工場内に設置しホットガスを使 ったテストを実施した．図 2 はその実証师の断面図で全長は 約 $12 \mathrm{~m}$ に及ぶ本格的実証炉である.

ホットガス炉のそもそもの発想は, 環境への負荷の大きな 溶融塩を使うソルトバス炉の代替である. ホットガス方式の 環境適合性を，主にエネルギー消費とその結果である二酸化 炭素 $\mathrm{CO}_{2}$ 排出量の観点から定量的にソルトバス炉方式と比 較評価し検証した．対象製品として合金工具鋼 SKD11 (JIS G 4404) を選定しその代表的熱处理 $\left(1,020^{\circ} \mathrm{C}\right.$ からの $500^{\circ} \mathrm{C}$ への焼入, 空冷後 $500^{\circ} \mathrm{C}$ での焼戻 2 回）に抢涑比較対象を 行った．図 3 にその結果を示すが，ホットガス方式により熱 処理での二酸化炭素 $\mathrm{CO}_{2}$ 排出量は大幅に減少している.

工具鋼等の精密加工品の熱処理歪及を少なくするための等 温熱処理に従来ソルトバス炉が尃ら用いられており, 低歪み に併せて光輝性に優れる真空焼入にても（合金）工具鋼の処 理が実施されている．上記合金工具鋼 SKD11にてガス冷却 で室温まで泠やしきる一般の真空焼入法とホットガスによる 等温熱処理による焼入法での比較熱処理テストを行った. 外 径 $150 \mathrm{~mm}$ 内径 $130 \mathrm{~mm}$ 高さ $30 \mathrm{~mm}$ のリングをサンプルに用

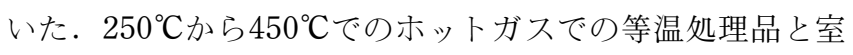
温への焼入品との焼入硬度の違いはほとんどみられず約 HRC63 硬さが得られた. 図 4 にみられるように熱処理歪み に打いては大きな違いが認められた， $400^{\circ} \mathrm{C}$ 等温熱処理では 熱処理歪みの平均值はほぼゼロに近く，そのバラッキは室温

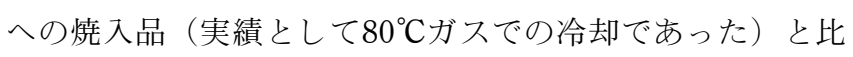
較すると半減している. 対象とした歪みは内径の真円度であ る. マイナス值は熱処理後真円度が減少した（良くなった） ことを意味する。

このようにホットガス方式の真空师ではエコで低歪みの高 品質品の処理が可能である.

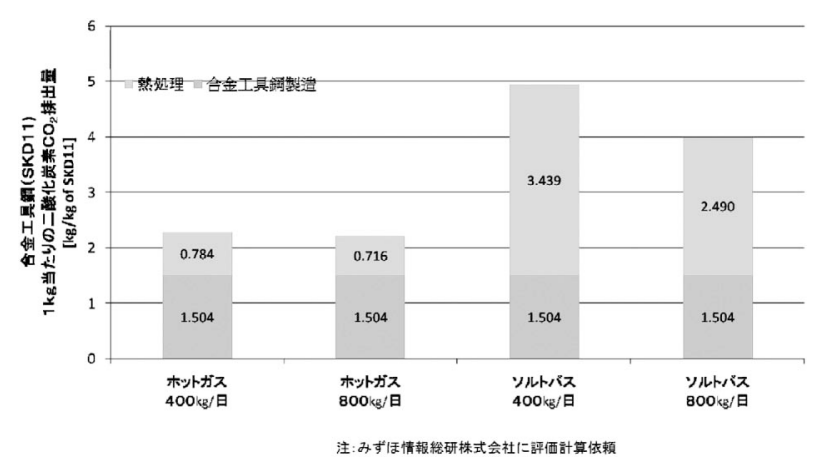

図 3 合金工具鋼 SKD11 でのホットガス方式とソルトバス炉 方式での環境影響評価 LCA 比較

Life cycle assessment by hot gas method and salt bath method for alloy tool steel SKD11
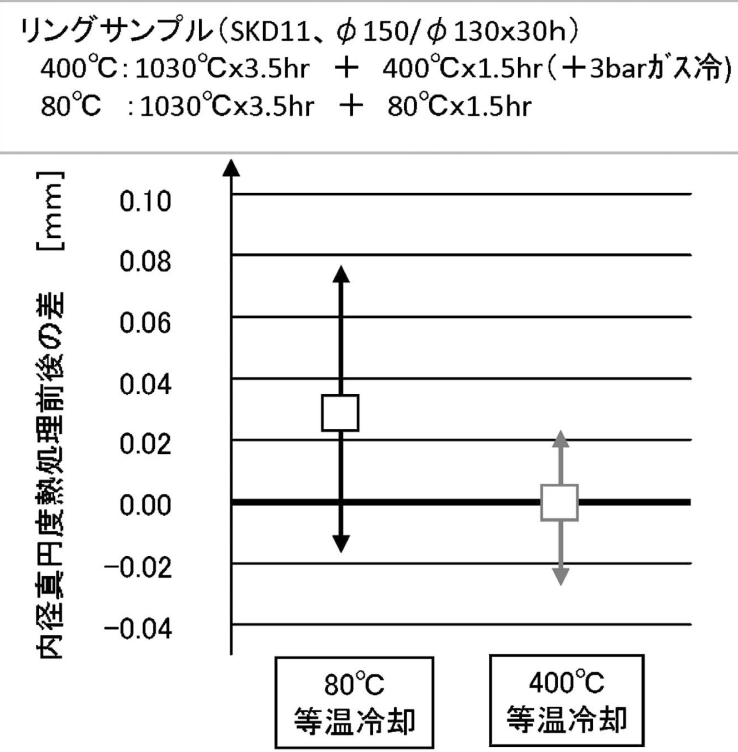

図 4 ホットガス方式真空炉等温熱処理品と通常真空焼入品で の熱処理歪み比較

Comparison of vacuum heat treatment distortion between hot gas isothermal treatment and general gas quenching 


\section{4. 浸炭マルクエンチ炉タイプのホットガス炉}

本事例は, 浸炭プロセスにホットガスを活用する試みで現 在開発進行中のものである.

ガス冷却において熱伝達係数を大きくし冷却能を向上させ
るために, 高ガス圧力化 (高ガス密度化), 高ガス流速化や 水素ガス或いはへリウムガスへのガス変更等が考えられる. しかしながら，ガス冷却による焼入ではコスト等の実際面か ら見ると現実的には鋼種やサイズがぞうしても限定されてし まう. 第二世代のホットガス炉は浸炭プロセスにホットガス

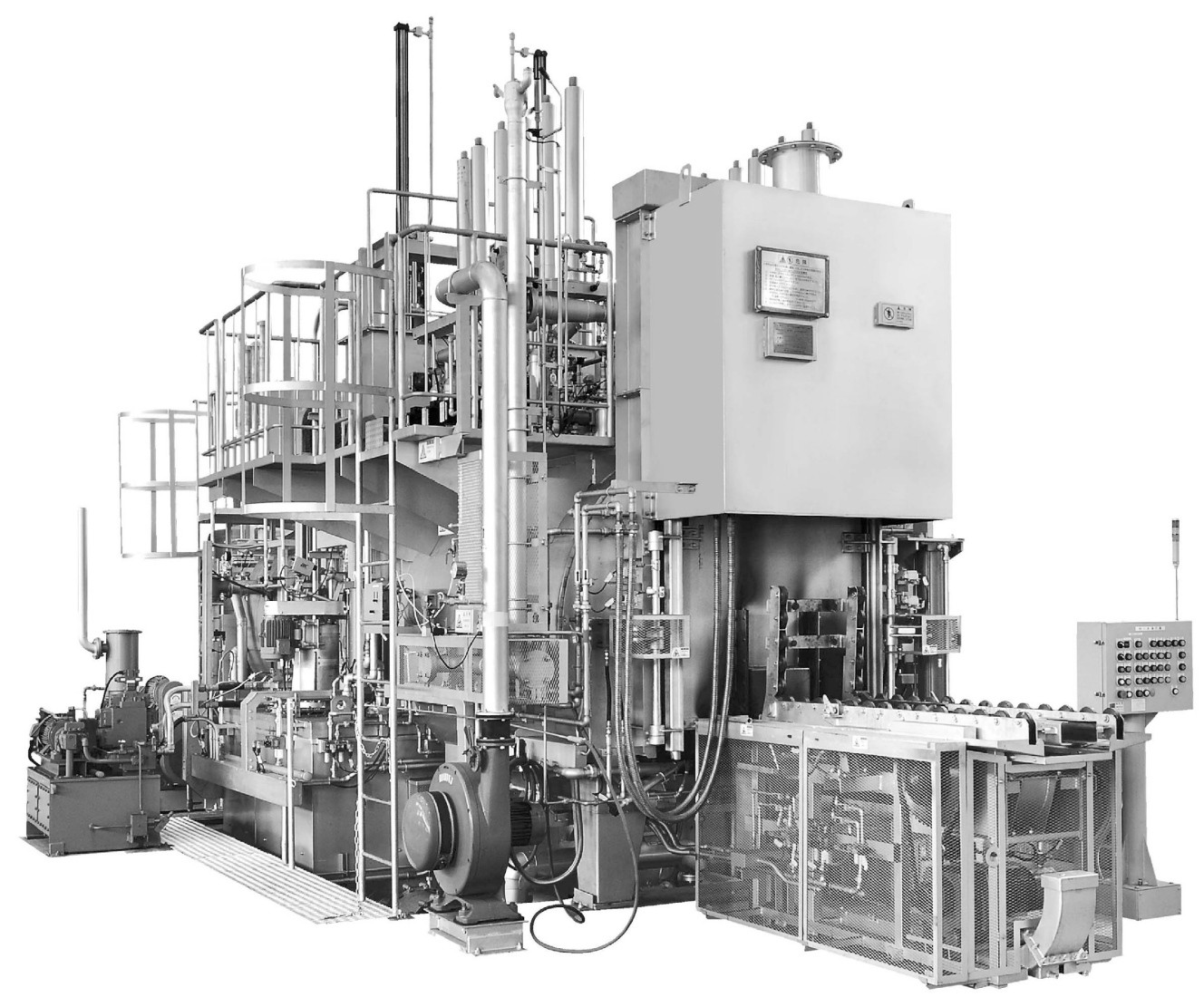

図 5 ホットガス方式による浸炭マルクエンチ炉

Hot gas furnace for carburizing and marquenching
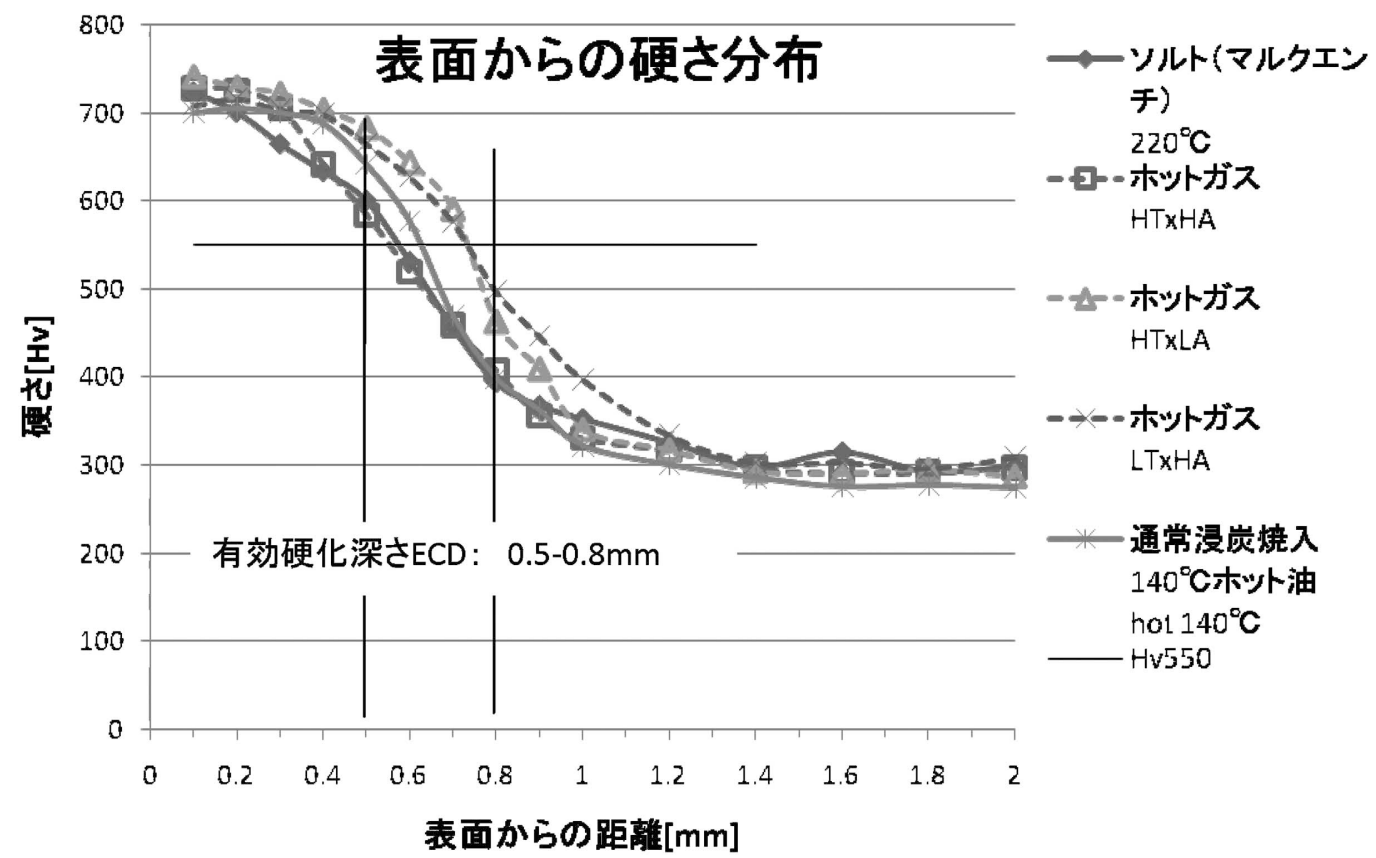

図 6 浸炭表面層の硬さ分布

Hardness profiles of carburized surface layer 


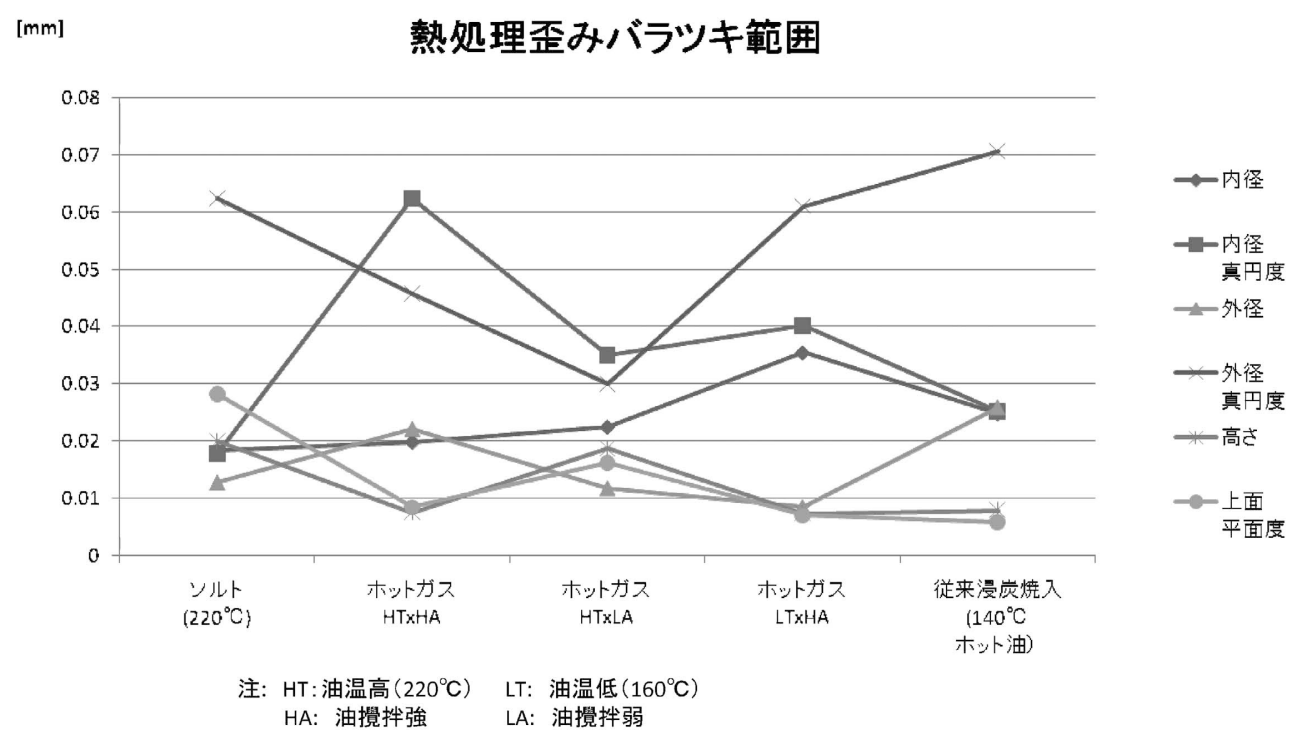

図 7 熱処理歪みのバラツキ

Dispersion of distortions caused by heat treatment

を適用するにあたって新しく開発した熱処理焼入油をオース テナイト温度からの焼入の第一ステップの冷却媒体として用 いて冷却初期の冷却能を確保し引き続いてホットガスによる マルクエンチ等温熱処理という形でのホットガス活用を浸炭 プロセスにて図ろうとするものである．浸炭ソルトマルクエ ンチ方式と同様の低歪み化を実現しエコプロセス化できるホ ットガスを浸炭プロセスに活用する方式である.

小リングでの熱処理テストにて比較的良好な結果が得られ ている. 外径 $75 \mathrm{~mm}$ 内径 $50 \mathrm{~mm}$ 高さ $20 \mathrm{~mm}$ の SCM420H （JIS G 4052）製のリングサンプルを用いて従来法との比較 を行った。従来法として浸炭ソルトマルクエンチ法と通常の 浸炭焼入（ $140^{\circ} \mathrm{C}$ ホット油）を選び，ホットガス方式浸炭マ ルクエンチ法では 3 条件を選び比較テストを実施した。ホ ットガス方式浸炭マルクエンチ法では焼入性に大きく関連す る冷却初期の熱処理焼入油の温度及び攪拌条件を変えた。 有 効硬化深さ ECD を $0.5 \mathrm{~mm} \sim 0.8 \mathrm{~mm}$ に設定して浸炭焼入焼 戻した浸炭表面層の硬度分布を図 6 に，熱処理による各寸法 の歪久のバラッキを図 7 に示す。本タイプのホットガス炉に おいても狙いはエコな（環境にやさしい）プロセスで高品質 （特に低熱処理歪み）な処理を実現することであるが，図 7 の熱処理歪みのバラツキのプロセスによる違いや条件設定に よる違いにみられるようにホットガス方式で全体として寸法 バラツキを小さくできる条件設定が可能であることがわかる.

本ホットガス方式による浸炭マルクエンチ処理の適用製品
の拡大に向けて現在取組中である.

\section{5. おわりに}

ホットガスという熱媒体を積極的に熱処理プロセスにおけ る一つのモジュールに活用し，環境時代にふさわしいエコ熱 処理プロセスの実現を図るべく各種熱処理プロセスへの適用 拡大に向けて現在も研究開発を進めている. 冷却能向上を図 るため他の媒体との組久合わせをも取り入れて，浸炭マルク エンチ処理に対してホットガスの適用拡大を図っている.

今後一層, 熱処理のエコプロセス化への一助として貢献で きるようホットガス方式の改善に努めている.

\section{（執筆者）}

株式会社谷口金属熱処理工業所

開発部 部長

浜辺晃弘

（問い合わせ先）

株式会社谷口金属熱処理工業所

開発部 企画担当

佐光真美子

干793-0042 愛媛県西条市喜多川853-16-1

TEL : 0897-55-5515 FAX : 0897-56-8877

URL:http://www.taniguchi-mht.co.jp 